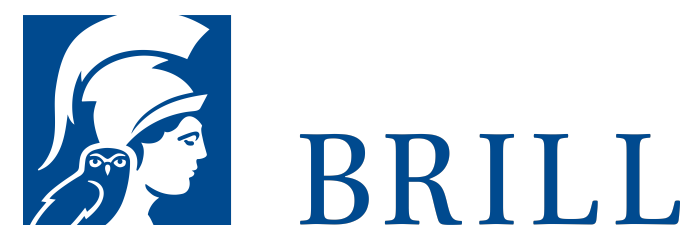

\title{
Bureaucratic Representation
}

Civil Servants and the Future of Capitalist Democracies

Author: Hall Thomas Wilson

This text discusses the central role of bureaucratic representation as a key vehicle for representing the general interests of most citizens in a way that is consistently superior to electoral systems in representative democracies, particularly large states. Though formal elections remain indispensable, bureaucracies in the capital, public and social sectors, have used their superior expertise and continuity, combined with social policies like affirmative action and equal pay, to achieve responsible discretion and creative implementation.

Readership

Academic and professional, as well as nationation and provincial/state libraries. Honours undergraduate, M.A. and Ph.D. faculty and students in Public Policy, Public Law and Social and Political Science departments, faculties and programmes. Selected faculty and students in equivalent programmes in North America, the UK and Commonwealth and Western Continental Europe focussed on comparative social and political institutions, democratic administration or social and political theory. Middle to higher level civil servants.

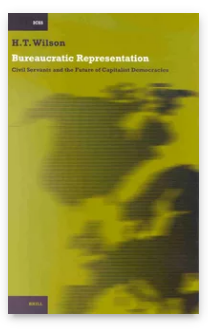

Pages: xii, 236

pp.

Language:

English

Subjects:

Comparative

Social Sciences,

Social Sciences

Publisher: Brill

Series:

International

Comparative

Social Studies,

Volume: 1

E-Book (PDF)

Released online: 22 Nov 2021

ISBN: 978-90-

04-39784-2

List price

USD. Â $\$ 103.00$

Hardback

Publication date: 22 May 2001

ISBN: 978-90-

04-12194-2

List price

USD Â A $\$ 103.00$ 
H.T. Wilson, Ph.D. (1968) in Political Science and Constitutional Law, Rutgers University, is Professor of Public Policy and Law at York University, Toronto. He has published extensively in public and social policy and social and political thought, including Sex and Gender (Brill, 1989).

For more information see brill.com

Order information: Order online at brill.com +44330 3330049 | customerservices@brill.com Submission information: brill.com/authors

Titles published by Brill | Fink, Brill | mentis or Brill | Schöningh: +49(o)71 5413279216 | brill@brocom.de 